DOI: $10.17951 / 1 r p .2021 .40 .3 .103-118$

\author{
AgnieszKa KozŁowska \\ Adam Mickiewicz University, Poznań, Poland \\ ORCID - 0000-0002-7614-6095
}

\title{
CLIMATE CHANGE EDUCATION IN POLISH AND BRITISH NATIONAL CURRICULUM FRAMEWORKS
}

Introduction: The presence and the content of climate education in national curriculum frameworks gains growing attention of researchers all over the world. Climate education addresses challenges of climate crisis and is an important part of ecological transformation in advanced economies. Research Aim: The aim of the study was to compare Polish core curriculum and English national curriculum, in terms of presence climate change education in curricula's content. Method: Material of the study were 2 documents: the Polish core curriculum and English national curriculum. The study was limited to key stages 1-3 in the National Curriculum which corresponds with kindergarten and primary school level in the Polish core curriculum. Content analysis was conducted using a categorisation key, with a set of words characteristic for a climate change concept. Results: Climate change is absent in studied curriculum standards. Only 3 out of 19 keywords were present in Polish base curriculum, whereas in English national curriculum - 5 of them. In both cases keywords did not demonstrate direct reference to climate change. Conclusion: Both studied documents are devoid of climate change education. The National Curriculum seems to be better in meeting the challenge of climate education, but differences are minor. The result may be caused by centralisation and politicization of the procedure of constructing both the studied documents, which may be an obstacle for introducing new aspects of knowledge and attitudes. Political context of the omission of climate change education in the national curriculum needs further studies under the concept of null curriculum of Elliot Eisner.

Keywords: national curriculum framework, climate education, environmental education, politicization of construction a curriculum, educational policy 


\section{INTRODUCTION}

Climate change education (CCE) is an important element of environmental education and is perceived as key to addressing climate change and more generally, ecological crisis. Five UN Assessment Reports of Intergovernmental Panel on Climate Change (IPCC), which have been published till now, in 1990, 1996, 2001, 2007, and $2014^{1}$ provided large body of evidence on ecological crisis and climate change: their possible effects, how they have been caused by human activity, and how humans might mitigate them or adapt to. In between, special reports were published including the last one, widely cited, on the effects of global warming of $1.5^{\circ} \mathrm{C}$ which envisions global ecological catastrophe if immediate and radical steps against climate change are not taken (IPCC, 2019).

Necessary measures to combat climate change phenomenon are based on circular economy, low carbon technologies, green energy, sustainable style of lives and policies which popularise them through "green" legislation. This green path of development, leading to more sustainable world, called "ecological transformation", is based on innovations and advanced technologies of industry 4.0, and needs highly educated society, with core knowledge on environment and climate change mechanisms, as well as equipped with high-level skills, such as creativity, critical thinking, out of the box thinking. Sustainability needs also change in the ecological paradigm, from anthropocentric into more biocentric, communitythinking one. It is clear, that education may play an important role in this change; moreover, the change is impossible without proper educational policy.

According to UNESCO, "[e]ducation is crucial to promote climate action. It helps people understand and address the impacts of the climate crisis, empowering them with the knowledge, skills, values and attitudes needed to act as agents of change" (UNESCO, n.d.)

Climate education and raising environmental awareness of the society is an obligation for parties of United Nations Framework Convention on Climate Change (UNFCCC) which entered into force in March 1994. Currently, 197 countries are parties to the Convention; the UK ratified the Convention as early as on 8 December 1993 and Poland - on 28 July 1994 ('United Nation Climate Change. Status of Ratification of the Convention', n.d.), so provisions of it have been obligatory for both states for almost 30 years. Several international work programs facilitating education on climate change were undertaken since then under UNFCCC umbrella, in reference to Art. 6 of the Convention, which was dedicated to education. They

1 The last, sixth report is under work and will be published in 2022, but several special and methodology reports which are part of it have been just published and are available at the IPCC website: https://www.ipcc.ch/reports/ [access: 14.04.2021]. 
were initiated during global summits - conferences of parties to the Convention (COPs). Widely known examples of them are: United Nations Alliance on Climate Change Education, Training and Public Awareness, established during COP 18 in Doha in 2012 and Art. 12 of Paris Agreement, enhancing the importance of Art. 6 of UNFCCC and the role of education in addressing climate change, which was accepted during COP 21 in 2015 in Paris (Kolleck, Well, Sperzel, Jörgens, 2017).

Both Poland and the UK, while preparing their national curricula which are now in force, were also obliged to follow the European Union (EU) policies on climate change, which had been initiated dozens of years ago and currently are very high on the EU political agenda (Forging a climate-resilient Europe - the new EU Strategy on Adaptation to Climate Change, 2021). There are also European Commission initiatives on education on climate change in the EU, e.g. European Climate Pact ('European Commission. Energy, Climate Change and Environment. European Climate Pact', n.d.) or Education for Climate Coalition ('European Commission. Education for Climate Coalition', n.d.), which empower schools, teachers, and environmentalists in their projects for climate.

Regardless of the fact that none of the above-mentioned UN or EU educational programs or initiatives refers to national curricula, revision of the content of public education seems to be a natural consequence of green shift in states' development. Alan Reid (2018) notices, referring to UN educational programs for Sustainable Development and changing of ecological paradigm in thinking on humans' attitude to environment, that "[ $\mathrm{t}$ ]hese movement of thought and their related foci for action have not gone unnoticed in the field of curriculum studies. Directly and indirectly, they both underscore and implicate a re-visioning and re-purposing of curriculum in environmental education and education more broadly" (Reid, 2018, p. 7). On the other hand, education for sustainability and particularly, climate change education, although it is so important for world's safety in future, happens to be perceived as "controversial" (Nicholls, Stevenson, 2015; Portney, 2015), and because of that is not treated in the same way as other fields of expertise. It is why I decided to examine, if and how climate change is present in national curriculum standards.

I chose Poland and England, because both the countries have got a national curriculum and in both it is a legislative document, proposed by government, then publicly negotiated, and accepted at the highest political level of government (Poland) or government and the parliament (UK). It suggests similar philosophy of education, which is behind, as a tool of political agenda. As such, curriculum is an element of national policy in education and may easily integrate international obligations, such as these derived from UNFCCC or EU strategic documents. 


\section{RESEARCH AIM AND QUESTION}

The aim of the study was a comparison of Polish core curriculum and the National Curriculum for England, in terms of presence of climate change education in curricula's content.

The question was, if and how CCE was represented in each document.

\section{RESEARCH METHOD AND SAMPLE CHARACTERISTICS}

Content analysis of public documents was conducted. The documents were:

1. Regulation of Polish Minister of National Education from 24 February 2017 on core curriculum for kindergarten and primary school - Rozporządzenie Ministra Edukacji Narodowej w sprawie podstawy programowej wychowania przedszkolnego oraz podstawy programowej kształcenia ogólnego dla szkoły podstawowej [...] (Dziennik Ustaw z dnia 24 lutego 2017, poz. 356).

2. The National Curriculum in England. Framework document. Department for Education, December 2014 ('The National Curriculum', n.d.).

Core curriculum for kindergarten and primary school of Poland was derived directly from legislative act published in the law data basis of Polish Sejm (ISAP - Internetowy System Aktów Prawnych, n.d.), which is free and most up to date source of legislative documents in Poland.

British national curriculum was obtained from the government website for the national curriculum ('The National Curriculum', n.d.).

The analyses encompassed curriculum for the key stages 1-3 in the UK (students aged 4-14) and kindergarten and primary school, stages 1-2 in Poland (students aged 3-15). The relation between age of pupils and stages of education in the British and Polish educational systems is pictured in Table 1. 
Table 1.

Organisation of educational system in Poland and England (ISCED 1-2)

\begin{tabular}{|c|c|c|c|c|}
\hline & \multicolumn{2}{|c|}{ United Kingdom } & \multicolumn{2}{|l|}{ Poland } \\
\hline Age (years) & $\begin{array}{c}\text { Key stages } \\
\text { in education } \\
\text { in England }\end{array}$ & $\begin{array}{c}\text { Year of obligatory } \\
\text { education }\end{array}$ & Educational stages in Poland & $\begin{array}{c}\text { Year of } \\
\text { obligatory } \\
\text { education }\end{array}$ \\
\hline $4-5$ & \multicolumn{2}{|c|}{ Primary school reception class } & \multirow{2}{*}{ kindergarten } & \\
\hline $5-6$ & \multirow{3}{*}{ K-1 } & 1 & & \\
\hline \multirow[t]{2}{*}{$6-7$} & & \multirow[t]{2}{*}{2} & $\begin{array}{c}\text { grade "0" } \\
\text { Primary school reception class }\end{array}$ & 1 \\
\hline & & & \multirow{3}{*}{$\begin{array}{c}\text { Stage } 1 \\
\text { Early school education } \\
\text { (grades I-III of primary } \\
\text { school) }\end{array}$} & 2 \\
\hline $7-8$ & \multirow{4}{*}{$\mathrm{K}-2$} & 3 & & 3 \\
\hline $8-9$ & & 4 & & 4 \\
\hline $9-10$ & & 5 & \multirow{5}{*}{$\begin{array}{c}\text { Stage } 2 \\
\text { Teaching by subject } \\
\text { (grades IV-VIII } \\
\text { of primary school) }\end{array}$} & 5 \\
\hline $10-11$ & & 6 & & 6 \\
\hline $11-12$ & \multirow{3}{*}{ K-3 } & 7 & & 7 \\
\hline $12-13$ & & 8 & & 8 \\
\hline $13-14$ & & 9 & & 9 \\
\hline
\end{tabular}

Source of data: https://eacea.ec.europa.eu/national-policies/eurydice/national-description_en [access: 22.06.2021].

\section{PROCEDURE OF ANALYSIS}

Both curricula were examined using a set of keywords, combined from 2 categorisation keys. The first one was taken from the work on the place of climate change in education system of Singapore (Chang, Pascua, 2017). The authors looked for links between policies on climate change and programmatic curriculum in the country. The words were: climate change, global warming, enhanced greenhouse effect, carbon cycle I footprint, fossil fuels, energy. To this set, I added: climate crisis, greenhouse gases, greenhouse gases emissions, climate change impacts / mitigation / adaptation, deforestation, reforestation, planetary boundaries / environmental limits, ecological transformation, sustainability, sustainable development, sustainable style of life, ecological consciousness. This complement was based partly on the categorisation key which I used in the previous study on environmental education in the Polish core curriculum (Kozłowska, 2021), and partly on the basis of compact publications on climate change and ecological crisis (Budziszewska, Kardaś, Bohdanowicz, 2021; Giddens, Sutton, 2017; Maslin, 2014) which were also used for proper translation of the terms applied in the Key. 
Both curriculum documents were searched according to keywords in their PDF versions. If a keyword was found, quality analysis was conducted to understand the context in which it was used. In the second round of the analysis, synonyms or equivalent expressions connected to the concept of climate change were searched, to be sure of results.

\section{RESULTS}

Table 2.

Keywords table and results of searching

\begin{tabular}{|c|c|c|c|c|}
\hline \multirow[b]{2}{*}{ No. } & \multicolumn{2}{|c|}{ The National Curriculum (England) } & \multicolumn{2}{|c|}{ Core curriculum (Poland) } \\
\hline & Keyword $^{*}$ & $\begin{array}{c}\text { Number of mentions } \\
\text { and the context }\end{array}$ & Keyword (PL) & $\begin{array}{c}\text { Number of mentions } \\
\text { and the context }\end{array}$ \\
\hline 1 & $\begin{array}{c}\text { climate change / } \\
\text { climate crisis }\end{array}$ & $\begin{array}{c}\text { K-3 / science/ } \\
\text { chemistry / Earth } \\
\text { and atmosphere / the } \\
\text { production of carbon } \\
\text { dioxide by human } \\
\text { activity and the impact } \\
\text { on climate (p. 207) }\end{array}$ & zmiana klimatu & 0 \\
\hline 2 & global warming & 0 & globalne ocieplenie & 0 \\
\hline 3 & greenhouse gases & 0 & gazy cieplarniane & 0 \\
\hline 4 & $\begin{array}{c}\text { enhanced } \\
\text { greenhouse effect }\end{array}$ & 0 & $\begin{array}{l}\text { nasilenie efektu } \\
\text { cieplarnianego }\end{array}$ & 0 \\
\hline 5 & $\begin{array}{c}\text { greenhouse gases } \\
\text { emissions }\end{array}$ & 0 & $\begin{array}{l}\text { emisje gazów } \\
\text { cieplarnianych }\end{array}$ & 0 \\
\hline 6 & carbon cycle & $\begin{array}{l}\text { K-3 / science / chemi- } \\
\text { stry / Earth and at- } \\
\text { mosphere / the carbon } \\
\text { cycle (p. 207) }\end{array}$ & $\begin{array}{c}\text { cykl węglowy / obieg } \\
\text { węgla w przyrodzie }\end{array}$ & $\begin{array}{l}\text { second stage of prima- } \\
\text { ry school / chemistry } \\
\text { / oxygen, hydrogen } \\
\text { and their chemical } \\
\text { compounds / (student) } \\
\text { describes carbon cycle }\end{array}$ \\
\hline 7 & carbon footprint & 0 & ślad węglowy & 0 \\
\hline 8 & fossil fuels & 0 & paliwa kopalne & 0 \\
\hline
\end{tabular}




\begin{tabular}{|c|c|c|c|c|}
\hline \multirow[b]{2}{*}{ No. } & \multicolumn{2}{|c|}{ The National Curriculum (England) } & \multicolumn{2}{|c|}{ Core curriculum (Poland) } \\
\hline & Keyword* & $\begin{array}{c}\text { Number of mentions } \\
\text { and the context }\end{array}$ & Keyword (PL) & $\begin{array}{c}\text { Number of mentions } \\
\text { and the context }\end{array}$ \\
\hline 9 & energy & $\begin{array}{l}23 \text { times, but without } \\
\text { clear connection to } \\
\text { climate change } \\
\text { K-3 / science/ biology } \\
\text { / material cycles and } \\
\text { energy / photosynthe- } \\
\text { sis / the dependence of } \\
\text { almost all life on Earth } \\
\text { on the ability of pho- } \\
\text { tosynthetic organisms, } \\
\text { [...] to use sunlight in } \\
\text { photosynthesis to build } \\
\text { organic molecules that } \\
\text { are an essential energy } \\
\text { store and to maintain } \\
\text { levels of oxygen and } \\
\text { carbon dioxide in the } \\
\text { atmosphere (p. 204) } \\
\text { K-3 / physics / energy } \\
\text { / fuels and energy } \\
\text { resources (p. 208) }\end{array}$ & energia & $\begin{array}{l}33 \text { times, but without } \\
\text { clear connection to } \\
\text { climate change } \\
\text { second stage of educa- } \\
\text { tion / geography / } \\
\text { geography of Europe } \\
\text { / differentiation of } \\
\text { energy sources in } \\
\text { countries of Europe; } \\
\text { relations between } \\
\text { natural environment } \\
\text { characteristics and } \\
\text { energy industry } \\
\text { (p. } 120,122,123)\end{array}$ \\
\hline 10 & $\begin{array}{l}\text { deforestation / } \\
\text { reforestation }\end{array}$ & $\begin{array}{l}\text { K-2 / science year } 4 \text { / } \\
\text { living things and their } \\
\text { habitats / pupils should } \\
\text { explore examples of } \\
\text { human impact (both } \\
\text { positive and negative) } \\
\text { on environments, for } \\
\text { example, the posi- } \\
\text { tive effects of nature } \\
\text { reserves, ecologi- } \\
\text { cally planned parks, } \\
\text { or garden ponds, and } \\
\text { the negative effects } \\
\text { of population and } \\
\text { development, litter or } \\
\text { deforestation (p. 185) }\end{array}$ & wylesianie / zalesianie & 0 \\
\hline 11 & climate change impact & 0 & skutki zmiany klimatu & 0 \\
\hline 12 & $\begin{array}{l}\text { climate change } \\
\text { mitigation }\end{array}$ & 0 & $\begin{array}{l}\text { przeciwdziałanie } \\
\text { zmianie klimatu }\end{array}$ & 0 \\
\hline 13 & $\begin{array}{c}\text { ecological } \\
\text { transformation }\end{array}$ & 0 & $\begin{array}{c}\text { transformacja } \\
\text { ekologiczna }\end{array}$ & 0 \\
\hline 14 & $\begin{array}{c}\text { adaptation to climate } \\
\text { change }\end{array}$ & 0 & $\begin{array}{c}\text { adaptacja do zmiany } \\
\text { klimatu }\end{array}$ & 0 \\
\hline
\end{tabular}




\begin{tabular}{|c|c|c|c|c|}
\hline \multirow[b]{2}{*}{ No. } & \multicolumn{2}{|c|}{ The National Curriculum (England) } & \multicolumn{2}{|c|}{ Core curriculum (Poland) } \\
\hline & Keyword ${ }^{*}$ & $\begin{array}{c}\text { Number of mentions } \\
\text { and the context }\end{array}$ & Keyword (PL) & $\begin{array}{c}\text { Number of mentions } \\
\text { and the context }\end{array}$ \\
\hline 15 & $\begin{array}{l}\text { planetary boundaries } \\
\text { / tipping points of the } \\
\text { climate system }\end{array}$ & 0 & $\begin{array}{c}\text { granice planetarne } \\
\text { / punkty krytyczne } \\
\text { w ziemskim systemie } \\
\text { klimatycznym }\end{array}$ & 0 \\
\hline 16 & environmental limits & $\begin{array}{l}\text { K-3 / science / che- } \\
\text { mistry / Earth and } \\
\text { atmosphere / Earth } \\
\text { as a source of limited } \\
\text { resources and the } \\
\text { efficacy of recycling } \\
\text { (p. 207) }\end{array}$ & $\begin{array}{l}\text { środowiskowe } \\
\text { granice wzrostu }\end{array}$ & 0 \\
\hline 17 & $\begin{array}{c}\text { sustainability / } \\
\text { sustainable } \\
\text { development }\end{array}$ & 0 & zrównoważony rozwój & $\begin{array}{l}\text { Introduction: a school } \\
\text { builds students' } \\
\text { attitudes of esteem to } \\
\text { natural environment, } \\
\text { promotes sustainable } \\
\text { development and } \\
\text { motivates them to eco- } \\
\text { logical activism and } \\
\text { interests in ecology } \\
\text { (p. 14) } \\
\text { biology / (student) } \\
\text { presents renewable and } \\
\text { non-renewable natural } \\
\text { resources and proposes } \\
\text { rational management } \\
\text { of them according to } \\
\text { the rules of sustainable } \\
\text { development (p. 141) }\end{array}$ \\
\hline 18 & sustainable style of life & 0 & $\begin{array}{c}\text { zrównoważony styl } \\
\dot{z} y c i a\end{array}$ & 0 \\
\hline 19 & $\begin{array}{c}\text { citizen initiatives for } \\
\text { climate }\end{array}$ & 0 & $\begin{array}{c}\text { aktywność obywatelska } \\
\text { na rzecz klimatu }\end{array}$ & 0 \\
\hline
\end{tabular}

* the list of keywords were combined from the categorisation keys of Chew-Chung Chang and Liberty Pascua (2017), Agnieszka Kozłowska (2021) and set of climate change literature (Budziszewska, Kardaś, Bohdanowicz, 2021; Giddens, Sutton, 2017; Maslin, 2014)

As it is shown in Table 2, climate change education practically does not exist neither in Polish core curriculum, nor in the counterpart document for England. From among 19 words, key for climate change concept, 16 did not occur in the core curriculum even once. The three which did - carbon cycle, energy, and sustainable development - were not referred to the climate change concept, however, they were in some way linked with human influence on natural environment. 
Further analysis of the content confirmed these observations: there is no word on climate change in the Polish national curriculum standard, at the level of primary school and kindergarten.

The National Curriculum for England is similar in this context. From among 19 words of categorisation key, 14 were absent. The present ones were the following: climate change, carbon cycle, energy, deforestation, and environmental limits. Just as in the Polish core curriculum, none of them referred directly to climate change. For example, the only mention on climate change, at the K-3 level, reads: "the production of carbon dioxide by human activity and the impact on climate".

\section{DISCUSSION}

The absence of climate change concept in Polish and British national curriculum frameworks is a surprise, as both Poland and the UK are obliged by international agreements, as the UNFCCC, to promote education and raise awareness on climate change. The result was unexpected also because of the fact that preparation and negotiation of both studied documents had taken place in the second decade of the $21^{\text {st }}$ century ( 2013 for the UK, 2016 for Poland), when both Poland and the UK were member states of the $\mathrm{EU}$ - one of the most green and sustainable economies in the world. While, as it was shown by kent Portney (2015), in the US, in some states, the idea of sustainability was legally questioned, and in this respect a new ecological paradigm and the concept of sustainability were controversial in the US - the EU incorporated it into the core of its main developmental strategy and uses legislative and non-legislative measures to convince the EU member states to implement the idea into practice (European Commission, 2019).

One of the possible reasons for the result of the study is politicised procedure of constructing the national curriculum in both countries. As Albert Victor Kelly (2009) noticed in his $6^{\text {th }}$ edition of handbook on the National Curriculum, "[...] education is essentially a political activity, that the education system is the device by which an advanced society prepares its young for adult life in the society [...]. The political context, then, is a major element in any scheme or system of education, and one without reference to which such a scheme or system cannot be properly understood" (p. 187).

The procedure and practice of preparing the curriculum in Poland and the UK justify the hypothesis that politics may be, in some way, a reason for the absence of climate change education in the studied documents. In both cases, the participation of educational experts in the negotiations of the national curriculum frameworks was limited, and official comments or statements on the lack of climate change in 
curriculum, however submitted by social partners, were ignored by responsible ministers. It is why the whole responsibility for the result - the eventual content of documents - must be taken by politicians.

In 2013, during public negotiations of the draft of the National Curriculum, Graham Research Institute on Climate Change and the Environment submitted some comments on the lack of climate change topic in a working paper for the National Curriculum (Hicks, Ward, Lester, 2013). They reckoned that the purpose of the Curriculum was "[...] to provide pupils with an introduction to the core knowledge that they need to be educated citizens" (Hicks, Ward, Lester, 2013, p. 3). In this context, the authors wrote that they were "[...] particularly concerned that the National Curriculum should provide pupils with the essential knowledge, skills and understanding about climate change, which could profoundly affect the lives of current and future generations" (p. 3). The authors criticised fragmentised character of climate education, disseminated between several subjects and projected only for the K-4 level of education. They wrote:

Given the UK's legally binding commitments to take action on climate change and to reduce greenhouse gas emissions, policy decisions are already being taken that will have important implications and consequences for younger generations. Young people must understand their role in creating emissions, and ways to mitigate climate change and adapt to those impacts of climate change that are now unavoidable. As such, the National Curriculum should ensure they are equipped with the core knowledge about climate change as part of their compulsory education. (Hicks, Ward, Lester, 2013, p. 5)

Others criticised limited debate on the National Curriculum, politicization and even "[...] de-intellectualisation of the curriculum debate" (Kelly, 2009, p. 235).

Public debate on the core curriculum in Poland also faced massive criticism. The document has been prepared in a hurry, without professional debate and involvement of highly regarded researchers and experts in the field. In 2016, the Ministry of National Education in Poland appointed several tens of experts to write a new core curriculum but refused to make their names public. They were revealed 2 years later in the atmosphere of scandal, after new Curriculum was published in 2017 and met media attacks of being fragmentary, inconsistent, unmodern, retrograde, too traditional, unsuitable to demands of contemporary and future world (Suchecka, 2018).

It is difficult to settle if the absence of climate change education in studied national curricula is the result of ignorance or rather conscious decision of decision-makers in educational policy. That question needs further studies, conducted under Elliot Eisner's concept of null curriculum (Eisner, 1985). The sense 
of null curriculum is that what is not learnt is equally important as what is put into educational standard. The reasons for omitting climate change education in a national curriculum are worthy of reflection and the role of politics in this respect seems a promising direction of studying.

Lack of climate change education in the national curriculum framework in Poland should be placed in a wider context of environmental education, which is treated marginally in the curriculum. In my previous work, I demonstrated that the concept of environmental education in curriculum is rooted in biology, moreover, in biological theory. Expressions as ecological crisis, climate change, ecological transformation do not occur in the document, which is written from an anthropocentric perspective and is silent in the topic of human responsibility for the ecological crisis (Kozłowska, 2021). These aspects - of necessity of changing humans' attitude to environment, revising environmental ethics, focusing on "change" in the climate change expression, developing thinking on climate change in a wider context, concentrating not only on scientific knowledge, but also biocentric thinking and doing - were raised by several authors (Attfield, 2018; González-Gaudiano, Meira-Cartea, 2019; Reid, 2018; Stevenson, Nicholls, Whitehouse, 2017). As Chew-Hung Chang pointed out in his book on climate change education, "[c]onsequently, I argue that CCE should be built on the foundations of moral responsibility to the environment" (Chang, 2016, p. 147). Similar point represents Magdalena Ochwat - a Polish researcher who postulates to introduce into school practice an interdisciplinary trend - ecological humanities (Ochwat, $2020 \mathrm{a}, 2020 \mathrm{~b})$. However, the discussion on the necessity of changing paradigm in environmental education in national curriculum, needs first to incorporate the topic into curriculum framework, and this is problematic not only in Poland and the UK. As it was demonstrated in the recent UNESCO report, which analysed 50 curricula frameworks or other strategic policy documents in 50 countries, "[e] ducation is not giving students sufficient knowledge to adapt, act and respond to climate change and environmental crises" (UNESCO, 2021).

Completing national curricula with the topic of climate change, placed in a wider context of environmental crisis, is a matter of emergency. Such a judgment is shared by Polish environmentalists, who may be a game changer in this matter. In June and July 2021, environmental and ecological NGOs in Poland, including UN Global Compact Network Poland, WWF, Młodzieżowy Strajk Klimatyczny [Youth Climate Strike], in partnership with business and science representatives, organised Round Table on Climate Change Education in Warsaw School of Economics. It was high-level meeting with participation of members of Polish parliament, government, and Chancellery of the President of the Republic of Poland. Although ministers for Environment and for Education did not come, this meeting 
was followed by media discussion on the need of climate change education in the national curriculum framework in Poland and made public exchange of opinions between ministers (Zaremba, 2021).

However, the level of engagement and readiness to introduce necessary changes into core curriculum of Poland seems to be higher between young people and citizens than civil servants. During the meeting, Szymon Kacprzak from Youth Climate Strike said:

Young people see this [the effects of climate change - A.K.], they have eyes, and they are more and more aware of changes of climate that occur. Unfortunately, they have no knowledge which could help them to cope with the results of observations. Because of a lack of school education on climate change, they often use internet as a source of information, and there they may find also fake news and the rhetoric of climate change neglecters, who persuade that there is "nothing to worry", whereas, literary, the earth is burning under our feet. (Zaremba, 2021)

Participants of Round Table decided to send a petition to Prime Minister Chancellery on an urgent need of climate change education in the national curriculum. The petition, initiated by WWF Poland, Youth Climate Strike and partners, was signed by over 60,000 of Polish citizens and was another voice concerning climate change education (\#Tak Dla Edukacji Klimatycznej, 2021), in addition to parliamentary interpellations which were submitted on behalf of citizens in 2020 and 2021 (Aniśko et al., 2020; Hanajczyk, 2021; Rutka et al., 2020). These initiatives did not cause expected answer from the government, however, minister for education agreed that climate change should be incorporated into national curriculum framework and promised that he would take necessary decisions in the nearest years (Gomulski, 2021). As it was said by David Orr (2004, cited in Stevenson, Nicholls, Whitehouse, 2017), "[w]e are still educating our children as if there were no planetary emergency". If we want to be responsible for the safe future of the planet, this must change.

\section{CONCLUSIONS}

Both studied documents - the Polish core curriculum and the National Curriculum for the UK, are practically devoid of climate change concept and knowledge at studied levels of education. Among 19 keywords which were examined in curricula, only 3 were present in the Polish national curriculum and only 5 in the English one. Those which were present, however, were not directly connected with 
the climate change concept. This absence of CCE exists regardless of official motions, which were submitted during public consultations of the documents, and regardless binding commitments of Poland and the UK to provide an education on climate change. The reason for that may lay in politicization of the procedure of preparation of the documents, and a treatment of educational policy and curriculum in an instrumental way, as a tool of political agenda. However, this explanation needs further studies.

Lack of climate change in national curriculum frameworks, one of the most important challenges in the contemporary world, may be also discussed under the concept of null curriculum, in which the subject of the study is not what is present, but what is absent in a curriculum. However, this needs further studies focused on the procedure and history of the construction of studied documents.

\section{STUDY LIMITATIONS}

The study covered only part of curricula, dedicated for kindergarten and primary school levels (key stages 1-3 in England, 1 and 2 level of education in Poland). Climate change, as a complicated concept, may be incorporated in a national curriculum at higher levels of education which had not been studied in this work. It is also important that national curriculum is only a framework for school curricula. There are no legal barriers to include climate change into school curriculum. To examine this, further studies are needed on school curricula and then, achieved curriculum.

\section{REFERENCES}

\#Tak Dla Edukacji Klimatycznej. (2021). Retrieved 21, June, 2021 from https://www. wwf.pl/edukacja-klimatyczna

Aniśko, T., Bochenek, M., Borys, P., Fabisiak, J., Gadowski, K., Gajewska, A., Zielińska, U. (2020). Interpelacja nr 14192 w sprawie treści dotyczacych zmian klimatycznych oraz ochrony środowiska $w$ podstawie programowej nauczania $w$ szkołach podstawowych i ponadpodstawowych. Warszawa: Sejm RP. Retrieved 19, July, 2021 from https://www.sejm.gov.pl/Sejm9.nsf/interpelacja.xsp?typ=INT\&nr=14192

Attfield, R. (2018). Environmental Ethics. A Very Short Introduction. Oxford: Oxford University Press.

Budziszewska, M., Kardaś, A., Bohdanowicz, Z. (2021). Klimatyczne ABC. Interdyscyplinarne podstawy współczesnej wiedzy o zmianie klimatu. Warszawa: Wyd. UW. Retrieved 15, January, 2021 from https://showyourstripes.info 
Chang, C.-H. (2016). Climate Change Education. Knowing, Doing and Being. LondonNew York: Routledge Taylor \& Francis Group.

Chang, C.-H., Pascua, L. (2017). The Curriculum of Climate Change Education: A Case for Singapore. Journal of Environmental Education, 48(3), 172-181. Retrieved 22, June, 2021 from https://search.ebscohost.com/login.aspx?direct=true\&db=eric\& $\mathrm{AN}=\mathrm{EJ} 1138648 \&$ lang $=\mathrm{pl} \&$ site $=$ ehost-live

Dziennik Ustaw z dnia 24 lutego 2017, poz. 356.

Eisner, E. (1985). Five Basic Orientations to the Curriculum. In: The Educational Imagination: On the Design and Evaluation of School Programs (pp. 61-86). New York: Macmillan.

European Commission. Education for Climate Coalition. (n.d.). Retrieved 21, January, 2021 from https://education-for-climate.ec.europa.eu/_en

European Commission. Energy, Climate Change and Environment. European Climate Pact. (n.d.). Retrieved 21, January, 2021 from https://ec.europa.eu/clima/policies/ eu-climate-action/pact_en

European Commission. The European Green Deal (2019). Brussels: European Commission. Retrieved 22, June, 2021 from https://eur-lex.europa.eu/resource.html?uri=cellar:b828d165-1c22-11ea-8c1f-01aa75ed71a1.0002.02/ DOC_1\&format=PDF

Forging a climate-resilient Europe - the new EU Strategy on Adaptation to Climate Change (2021). Brussels: European Commission.

Giddens, A., Sutton, P.W. (2017). The Environment. In: Sociology (VIII, pp. 152-199). Cambridge: Polity Press.

Gomulski, M. (2021). Minister Czarnek: edukacja klimatyczna w szkołach od 2023 r. Rzeczpospolita. Retrieved 19, July, 2021 from https://klimat.rp.pl/ludzie/8858minister-czarnek-edukacja-klimatyczna-w-szkolach-od-2023-r/

González-Gaudiano, E.J., Meira-Cartea, P.Á. (2019). Environmental Education under Siege: Climate Radicality. Journal of Environmental Education, 50(4-6), 386-402. https://doi.org/10.1080/00958964.2019.1687406

Hanajczyk, A. (2021). Interpelacja nr 19484 do ministra edukacji narodowej w sprawie edukacji klimatycznej. Sejm RP. Retrieved from https://sejm.gov.pl/Sejm9.nsf/ InterpelacjaTresc.xsp?key=BY5C2T

Hicks, N., Ward, B., Lester, S. (2013). Climate Change in the National Curriculum in England: Submission to a Consultation by the Department of Education. London: Graham Research Institute on Climate Change and the Environment.

IPCC. (2019). Summary for Policymakers. In V. Masson-Delmotte. P. Zhai. H.-O. Portner. D. Roberts. J. Skea. E. Calvo Buendia (eds.). Climate Change and Land. An IPCC Special Report on Climate Change, Desertification, Land Degradation, Sustainable Land Management, Food Security, and Greenhouse Gas Fluxes in Terrestrial Ecosystems 
(pp. 1-36). Intergovernmental Panel on Climate Change. Retrieved 15, April, 2021 from https://www.ipcc.ch/site/assets/uploads/sites/4/2020/02/SPM_Updated-Jan20.pdf ISAP - Internetowy System Aktów Prawnych. (n.d.). Retrieved 21, January, 2021 from https://isap.sejm.gov.pl/

Kelly, A.V. (2009). The Curriculum. Theory and Practice (VI, Vol. 1). Los AngelesLondon: SAGE.

Kolleck, N., Well, M., Sperzel, S., Jörgens, H. (2017). The Power of Social Networks: How the UNFCCC Secretariat Creates Momentum for Climate Education. Global Environmental Politics, 17(4), 106-126. https://doi.org/10.0.4.138/GLEP_a_00428 Kozłowska, A. (2021). Edukacja ekologiczna w polskiej podstawie programowej (Environmental education in the Polish base curriculum). Rocznik Pedagogiczny, 44, accepted for printing. https://doi.org/10.2478/rp-2021-0010

Maslin, M. (2014). Climate Change. A Very Short Introduction. Oxford: Oxford University Press.

Nicholls, J., Stevenson, R.B. (2015). Queensland Teachers' Understandings of Education for Climate Change. Education Graduate Student Symphosium, 1, 21-27.

Ochwat, M. (2020a). (Współ)myslenie w humanistyce. Literackie ekokształcenie w epoce antropocenu. Polonistyka. Innowacje, 12, 31-51. https://doi.org/10.14746/pi.2020.12.3

Ochwat, M. (2020b). Edukacja polonistyczna wobec kryzysu klimatycznego - rozpoznania i rekomendacje dydaktyczne. Annales Universitatis Mariae Curie-Sklodowska. Lublin-Polonia, V, 185-204. https://doi.org/10.17951/en.2020.5.185-204

Portney, K.E. (2015). Sustainability and the Roots of Controversy. In: Sustainability (pp. 57-85). Cambridge-London: The MIT Press.

Reid, A. (2018). Curriculum and Environmental Education. Perspectives, Priorities and Challenges. (ed. A. Reid) (Vol. 1). London-New York: Routledge.

Rutka, M., Gill-Piątek, H., Kucharska-Dziedzic, A., Obaz, R., Kopiec, M., Krutul, P. (2020). Interpelacja 9884 do ministra klimatu w sprawie wsparcia edukacji klimatycznej prowadzonej przez organizacje pozarządowe. Warszawa: Sejm RP. Retrieved from https://sejm.gov.pl/Sejm9.nsf/InterpelacjaTresc.xsp?key=BSNAAB Stevenson, R.B., Nicholls, J., Whitehouse, H. (2017). What Is Climate Change Education? Curriculum Perspective. https://doi.org/10.1007/s41297-017-0015-9

Suchecka, J. (2018). Znamy nazwiska ekpertów Anny Zalewskiej! Walka o ich ujawnienie trwała od listopada 2016. Gazeta Wyborcza. Retrieved 19, July, 2021 from https://wyborcza.pl/7,75398,23774757,znamy-nazwiska-ekspertow-anny-zalewskiej-walka-o-ujawnienie.html

The National Curriculum. (n.d.). Retrieved 22, June, 2021 from https://www.gov.uk/ government/collections/national-curriculum

UNESCO. (n.d.). Education for climate action. Retrieved 11, July, 2021 from https:// en.unesco.org/themes/education-sustainable-development/cce 
UNESCO. (2021). Learn for our planet: a global review of how environmental issues are integrated in education. Retrieved 8, July, 2021 from https://unesdoc.unesco. org/ark:/48223/pf0000377362

United Nation Climate Change. Status of Ratification of the Convention. (n.d.). Retrieved 9, July, 2021 from https://unfccc.int/process-and-meetings/the-convention/ status-of-ratification/status-of-ratification-of-the-convention

Zaremba, J. (2021). Okrągły stół dla edukacji klimatycznej. Młodzi aktywiści złożą petycję do KPRM. Wirtualna Polska. Retrieved 19, July, 2021 from https://wiadomosci.wp.pl/okragly-stol-dla-edukacji-klimatycznej-mlodzi-ludzie-to-widza-i-sa-coraz-bardziej-swiadomi-6661534191168256a

EDUKACJA KLIMATYCZNA W POLSKIEJ I BRYTYJSKIEJ PODSTAWIE PROGRAMOWEJ

Wprowadzenie: Obecność i treść edukacji klimatycznej w podstawie programowej (narodowych standardach programowych) interesuje coraz większą grupę badaczy na całym świecie, w miarę jak transformacja ekologiczna, stanowiąca odpowiedź na kryzys klimatyczny, staje się priorytetem w politykach rozwojowych rozwiniętych gospodarczo państw świata. Cel badań: Celem pracy jest porównanie polskiej i angielskiej podstawy programowej pod kątem obecności w niej edukacji klimatycznej. Metoda badań: Materiał do analizy stanowiły dwa dokumenty: Podstawa programowa kształcenia ogólnego oraz jej brytyjski odpowiednik, The National Curriculum for England. Badaniem objęto etap kształcenia dzieci w wieku przedszkolnym i szkolnym (polska szkoła podstawowa, angielskie etapy edukacyjne K-1, K-2, K-3). Zastosowana w pracy metoda badawcza to analiza tekstu, oparta na zmodyfikowanym kluczu kategoryzacyjnym, zawierającym słowa kluczowe dla terminu „zmiana klimatu”. Wyniki: Zagadnienie zmiany klimatu jest niemal nieobecne w polskiej podstawie programowej dla badanych etapów edukacyjnych (przedszkole i szkoła podstawowa). Tylko 3 z 19 kategorii znaczeniowych z Klucza było obecnych w Podstawie, ale nie są one bezpośrednio odniesione do zmiany klimatu. Angielski odpowiednik Podstawy zawiera 5 słów z klucza kategoryzacyjnego, podobnie, bez bezpośrednich odniesień do zmiany klimatu, choć w nawiązaniu do degradacji środowiska naturalnego. Wnioski: Oba badane standardy programowe są pozbawione edukacji klimatycznej. Angielska podstawa programowa okazała się nieco bliższa temu wyzwaniu współczesności, jednak różnica jest niewielka. Przyczyną braku tego zagadnienia w Podstawie może być, podobna w obu krajach, scentralizowana i upolityczniona procedura tworzenia tego dokumentu, która nie sprzyja zmianie treści i wprowadzaniu nowych wątków. Warto dokładniej zbadać polityczny kontekst jako prawdopodobną przyczynę ominięcia edukacji klimatycznej w obu podstawach programowych, jako uwarunkowania „nieobecnego programu” Eisnera.

Słowa kluczowe: podstawa programowa, edukacja ekologiczna, edukacja klimatyczna, upolitycznienie procedury tworzenia Podstawy, polityka edukacyjna 